\title{
Democracias liberal e iliberal na América Latina
}

\begin{tabular}{c}
\hline \hline Peter H. Smith \\
Departamento de Ciência Política \\
Universidade de Chicago \\
Melissa R. Ziegler \\
Departamento de Ciência Política \\
Universidade de Chicago \\
\hline \hline
\end{tabular}

\begin{abstract}
Resumo: Este artigo examina a incidência da democracia liberal e "iliberal" na América Latina, de 1978 a 2004. Demonstra, em primeiro lugar, que a democracia iliberal - que combina eleições livres e justas com limitações sistemáticas aos direitos dos cidadãos - tornou-se a regra em toda a região. Em segundo lugar, mostra que as transições de regimes quase sempre levaram à variante iliberal da democracia. Terceiro, a análise logit de eventos raros revela que duas variáveis - hiperinflanção e eleições presidenciais - tiveram um impacto considerável sobre o movimento na direção de uma democracia mais plena. Como uma espécie de choque econômico de curto prazo, a hiperinflação produziu uma insatisfação generalizada; nessas circunstâncias, uma vez chegada a chance de votar, os cidadãos elegeram candidatos reformistas que, tão logo no poder, removeram obstáculos ao exercício de direitos civis. Um tal cenário aumenta substancialmente a probabilidade da transição da democracia iliberal para a democracia liberal.
\end{abstract}

Palavras-chave: democracias liberal e iliberal; direitos políticos e civis; transição política

Abstract: This paper examines the incidence of liberal and "illiberal" democracy in Latin America from 1978 through 2004. It demonstrates, first, that illiberal democracy - which combines free and fair elections with systematic constraints on civil liberties - has become the norm throughout the region. Second, it shows that regime transitions have most often ended not in liberal democracy, but in illiberal democracy. Third, rare events logit analysis reveals that three variables - hyperinflation, general strikes, and presidential elections - have had significant impact on transitions toward fuller democracy. As a form of short-term economic shock, hyperinflation generates widespread discontent which sometimes results in general strikes; given the opportunity to vote, citizens elect reformist opposition candidates who, once in office, remove controls on civil liberties. This scenario substantially increases the likelihood of transition from illiberal to liberal democracy.

Keywords: liberal and illiberal democracy; political and civil rights; political transition 
A América Latina adentrou uma era de democracia com adjetivos (COLLIER e LEVITSKY, 1997). Apesar de as eleições nacionais terem se tornado abertas e competitivas, as unidades políticas democráticas na região são frequentemente descritas como incompletas, parciais, ocas ou rasas (dependendo da metáfora que se prefira). A autoridade para tomar decisões parece se revelar superconcentrada, hiperpresidencialista ou delegatória; a representação política padece com a fragmentação dos partidos políticos e com sistemas partidários "rudimentares"; ordenamentos jurídicos e instituições judiciais tendem a ser subservientes, parciais ou incompetentes; políticas públicas adotadas para fazer frente a problemas candentes - pobreza, desigualdade, criminalidade - parecem profundamente inadequadas (O'DONNELL, 1994; MAINWARING \& SCULLY, 1995; LUSTIG, 1995; DIAMOND, 1999). Em meio a essa cacofonia de adjetivos, existe uma preocupação comum: avaliar a qualidade da vida democrática (O’DONNELL, CULLELL \& IAZZATA, 2004; DIAMOND \& MORLINO, 2005). Todos se sentem tentados a perguntar: que tipo de democracia vem se formando na América Latina?

Abordaremos essa questão aqui enfocando a distinção entre democracia "liberal" e "iliberal". Como descreve Fareed Zakaria, a democracia "liberal" não pressupõe apenas eleições livres e justas, mas também a proteção constitucional dos direitos dos cidadãos; democracia "iliberal" ocorre quando eleições livres e justas associam-se à refutação sistemática de garantias constitucionais. Observando o mundo no final dos anos 1990, Zakaria percebeu um fenômeno que se espalhava:

"Regimes democraticamente eleitos, com frequência aqueles que foram reeleitos ou confirmados no poder por meio de referendos, têm ignorado rotineiramente os limites constitucionais a seus poderes e destituído seus cidadãos de garantias e direitos fundamentais. Do Peru à Autoridade Palestina, de Serra Leoa à Eslováquia, vemos a emergência de um fenômeno preocupante na cena internacional - a democracia iliberal." (ZAKARIA, 1997; também SCHEDLER, 2002, 2006)

Qual tem sido a situação recente na América Latina? Este artigo aborda essa questão sob diversos aspectos. Primeiro, explica e aplica os conceitos de democracia liberal e iliberal. Enfocando o período de 1978 a 2004, definido por alguns como o terceiro e último "ciclo" de democratização na América Latina (SMITH, 2004; 2005; HAGOPIAN \& MAINWARING, 2006), este estudo prossegue medindo a incidência e a evolução dessas duas variantes (e também da não. democracia). Identifica e traça rotas de transição entre os diferentes tipos de regime político; mais detalhadamente, explora a possibilidade de que a democracia iliberal possa oferecer um caminho recorrente em direção à democracia liberal. 
Finalmente, de modo a avaliar a lógica e as circunstâncias da transição entre regimes, examina correlatos estruturais de movimentos na direção da democracia política, questionando se há relações observáveis entre mudanças de regime e variáveis econômicas, sociais e políticas ${ }^{1}$.

Esta abordagem tem limitações. Um dos principais déficits no que diz respeito à democracia latinoamericana refere-se ao estado de direito. Como veremos adiante, tratar dos direitos dos cidadãos ajuda a realçar esse aspecto, mas apenas indiretamente, como um de diversos componentes de uma ampla definição operacional. Reconhecemos que a capacidade do Estado, a governança e o ordenamento jurídico representam fatores decisivos para a avaliação da qualidade democrática. Opor democracia liberal à iliberal pode representar uma importante contribuição nesse esforço, mas não responderá todas as questões relevantes.

\section{Definindo o problema: variações de democracia}

A análise começa explorando a relação empírica entre processos eleitorais e direitos dos cidadãos. Aquilo que chamaremos aqui de "democracia eleitoral" se refere à existência de eleições livres e justas - nada menos e nada mais. A maioria dos cidadãos adultos deve ter o direito de votar e deve haver uma competição genuína entre candidatos rivais disputando um posto em nível nacional. Por seu turno, a noção de "direitos dos cidadãos" envolve um leque de garantias fundamentais - direito de formar e adentrar organizações, direito de expressão, acesso a fontes alternativas de informação (através do exercício da liberdade de imprensa) e por aí afora. Tais proteções não apenas asseguram que grupos e indivíduos apresentem suas visões e ideias, mas também oferecem a base para uma competição real entre candidatos ao poder. De acordo com o uso corrente, as eleições constituem um componente procedimental da democracia, enquanto os direitos seriam um componente substantivo.

A análise engloba 19 países da América Latina - todos os países da região, com a conspícua exceção de Cuba². A cada ano, entre 1978 e 2004, os sistemas eleitorais foram classificados seguindo um esquema triplo. Se as eleições foram livres e justas, com competição aberta por apoio em meio à população em idade

\footnotetext{
${ }^{1}$ Em termos de método e abordagem, este estudo tem uma marcada semelhança com o pioneiro ensaio de Scott Mainwaring e Aníbal Pérez-Liñán (2005). A principal diferença é que Mainwaring e Pérez-Liñán procuram explicar as origens e o ritmo de consolidação do ciclo de democratização que teve lugar a partir de 1978, enquanto aqui o esforço é compreender as alterações políticas que tiveram lugar dentro do próprio ciclo. Aqui, portanto, a classificação de regimes políticos será mais detalhada. Além disso, se eles, por um lado, concluem que as mudanças no ambiente político internacional foram essenciais para a explosão de democracia na América Latina, esse fator é, por outro lado, percebido mais ou menos como uma constante durante todo o período de que trata este estudo.

${ }^{2}$ Cuba foi excluída em razão de não haver promovido eleições competitivas para o executivo nacional durante o período considerado (SMITH, 2005, p.24).
} 
eleitoral, o sistema é classificado como "democrático". Eleições livres, mas não justas - quando apenas um dos candidatos teve chances reais de vencer o pleito, quando qualquer candidato ou partido com amplo apoio popular foi impedido de concorrer ou quando os líderes eleitos foram obrigados a dividir ou ceder o poder efetivo a grupos não eleitos - são consideradas "semidemocráticas". Eleições que não ocorreram, foram claramente fraudulentas, conduzidas por regimes autoritários ou realizadas sob ocupação militar por uma potência estrangeira foram classificadas como "não-democráticas".

Para operacionalizar o conceito de direitos dos cidadãos, múltiplas fontes foram consultadas: relatórios anuais sobre as "liberdades civis", publicados pela Freedom House, o banco de dados de direitos humanos Cingranelli-Richards, estabelecido recentemente, assim como narrativas documentais. Esse processo gerou uma variável ordinal-nominal com três valores: extensivos, limitados e mínimos. Direitos civis extensivos correspondem a democracias "liberais" ou semidemocracias; limitações parciais, mas sistemáticas dos direitos caracterizam unidades políticas "iliberais"; e direitos mínimos refletem níveis duros (agudos) de repressão (ver Anexo 1 para uma explicação detalhada do aparato metodológico).

A pesquisa utilizou os resultados anuais de cada um dos 19 países para cada ano entre 1978 e 2004. Para obter um cenário composto abrangendo eleições e direitos dos cidadãos, como aparece na Tabela 1, as duas variáveis foram cruzadas. Ou seja, em lugar de compilar pontuações cumulativas, o estudo explorou a relação entre as dimensões isoladas. Tanto em termos teóricos como empíricos, duas das nove células arrolam categorias nulas - democracia repressiva e ditadura liberal. O procedimento produz, assim, uma tipologia de 7 modalidades.

Tabela 1

Democracia, eleições e direitos dos cidadãos: uma tipologia

\begin{tabular}{|c|c|c|c|}
\hline \multicolumn{4}{|c|}{ Caráter das eleições } \\
\hline Direitos dos cidadãos & Livres e justas & Livres e não justas & Sem eleições \\
\hline Expansivos & Democracia liberal & $\begin{array}{c}\text { Semidemocracia } \\
\text { liberal/permissiva }\end{array}$ & \\
\hline Limitados & Democracia iliberal & $\begin{array}{c}\text { Semidemocracia } \\
\text { iliberal/restritiva }\end{array}$ & moderado (dictabranda) \\
\hline Mínimos & & $\begin{array}{c}\text { Semidemocracia } \\
\text { repressiva }\end{array}$ & “linha dura" (ditadura) \\
\hline
\end{tabular}


Em sua maioria, as democracias liberais cumprem todos os critérios mais amplamente aceitos que caracterizam uma democracia plena (DAHL, 1971, p.1.3); um caso exemplar seria o Chile do período da Concertación. Regimes que combinam eleições livres e justas com restrições parciais, mas sistemáticas, aos direitos dos cidadãos correspondem a democracias "iliberais": a Bolívia desde o início da década de 1980 e a Argentina sob Carlos Menem são casos exemplares. Para fins de definição, regimes sem eleições - ou com eleições fictícias - são autoritários. Autocracias de linha-dura ou ditaduras (como o Chile de Augusto Pinochet ou a Guatemala de Efraín Ríos Montt) reprimem incansavelmente os direitos de seus cidadãos; ditaduras tradicionais, por vezes chamadas de "ditabrandas", com frequência permitem o exercício parcial de direitos civis, mas somente dentro de limites estreitos (como no Brasil, durante o início dos anos 1980). Autocracias não promovem direitos civis básicos; se o fizessem, não seriam realmente autocráticas.

Em parte por conta de seu estatuto interino, semidemocracias eleitorais poderiam tolerar graus variados de exercício de direitos civis; algumas foram mais liberais, outras mais repressivas, mas no mais das vezes foram consideradas "iliberais". Conforme demonstra outro estudo (SMITH, 2005), semidemocracias tiveram quase sempre uma vida curta; sob a fachada de eleições arranjadas, ofereceram saídas seguras para dirigentes autoritários.

Tabela 2

Perfil dos regimes políticos na América Latina, 1978-2004

\begin{tabular}{|l|c|c|c|}
\hline \multicolumn{4}{|c|}{ Caráter das eleições } \\
\hline Direitos civis & Livres e justas & Livres e não justas & Sem eleições \\
\hline Expansivos & 108 & 6 & 0 \\
\hline Limitados & 194 & 69 & 41 \\
\hline Mínimos & 0 & 25 & 70 \\
\hline Total & 302 & 100 & 111 \\
\hline
\end{tabular}

Para demonstrar as implicações práticas da tipologia, a Tabela 2 apresenta um cruzamento para todos os países nos anos de 1978 a 2004. A amostra revela um perfil empírico da prática política durante a "terceira onda" de transformação política na América Latina. Democracias (de todos os tipos) apareceram $60 \%$ das vezes, semidemocracia 19\% e não-democracia 21\% (o Apêncide 2 contém uma listagem de regimes por países). O resultado mais surpreendente foi que a 
democracia iliberal, combinando eleições livres e justas com restrições aos direitos civis, foi o tipo mais frequente, aparecendo $40 \%$ das vezes. A democracia iliberal provou ser o regime modal.

\section{Movimentos, caminhos e transições}

A movimentação entre essas categorias serve de base para a análise estatística. A tipologia oferece uma oportunidade sugestiva para interpretar a mudança de regime como uma espécie de jogo de amarelinha político, na medida em que países migram de célula à célula. México, por exemplo, passou de regime autoritário moderado (sob o PRI) à semidemocracia iliberal (sob Carlos Salinas e Ernesto Zedillo) e, finalmente, à democracia liberal (2002-2004). Chile e Argentina foram rapidamente de ditaduras de linha dura, passando por breves interlúdios liberais, a democracias liberais; o Brasil, por sua vez, passou do governo militar pela semidemocracia até a democracia iliberal. Por outro lado, Venezuela e Colômbia moveram-se na direção contrária, de democracia liberal à iliberal (Colômbia) ou à semidemocracia iliberal (Venezuela). Utilizada dessa maneira, a tipologia nos permite traçar trajetórias políticas ao longo do tempo.

Em muitas instâncias, o movimento ao longo dessas categorias é de escala muito mais modesta do que as grandiosas "transições" descritas na literatura correspondente - que tende a enfocar as mudanças de maior envergadura, de modelos autoritários a formas democráticas de governo. Algumas das células dessa tipologia, especialmente aquelas que se situam no campo da semidemocracia eleitoral, na verdade retratam antes "momentos", "situações" ou "arranjos" do que propriamente "regimes" estabelecidos. Sob governos autoritários, as idas e vindas entre "linha dura" a "moderado" geralmente refletem mais oscilações, flutuações ou decisões táticas do que transformações sistêmicas. De fato, muitos movimentos entre células podem ser mais bem compreendidos como deslocamentos, passagens, comutações, modificações ou mudanças do que transições propriamente ditas. Ao mesmo tempo, essa classificação abre caminho ao processo gradual de transição democrática, permitindo que seus elementos constitutivos sejam detectados e analisados. A democracia, como veremos, chega com frequência em prestações.

\section{Democracia liberal e iliberal: ritmos, incidência e mudança}

Eleições competitivas, sem dúvida, se tornaram o instrumento preferencial para a alocação do poder político na América Latina. A Figura 1 mostra o acentuado aumento na incidência da democracia eleitoral entre 1978 e 2004. Em meados da década de 1970, uma era de intensa repressão militar, apenas três países podiam apresentar um histórico consistente de eleições livres e justas: Colômbia, Costa 
Rica e Venezuela. Aquilo que se tornou um ciclo persistente de democratização começou a fincar pé inicialmente nos Andes, no Equador e no Peru, elevando o número de democracias eleitorais em 1980 a um total de seis. A década seguinte viu a restauração da democracia quase por toda a parte na América do Sul, com a adição da Argentina e do Uruguai, em 1985, e do Brasil e do Chile, em 1990. Os anos 1990 trouxeram a implementação de democracias inéditas no México, na América Central e no Caribe. Em 2004, 17 dos 19 países realizavam eleições livres e justas, com as únicas exceções do Haiti e da Venezuela.

\section{Figura 1}

\section{Ascensão da democracia eleitoral na América Latina (1972-2004)}

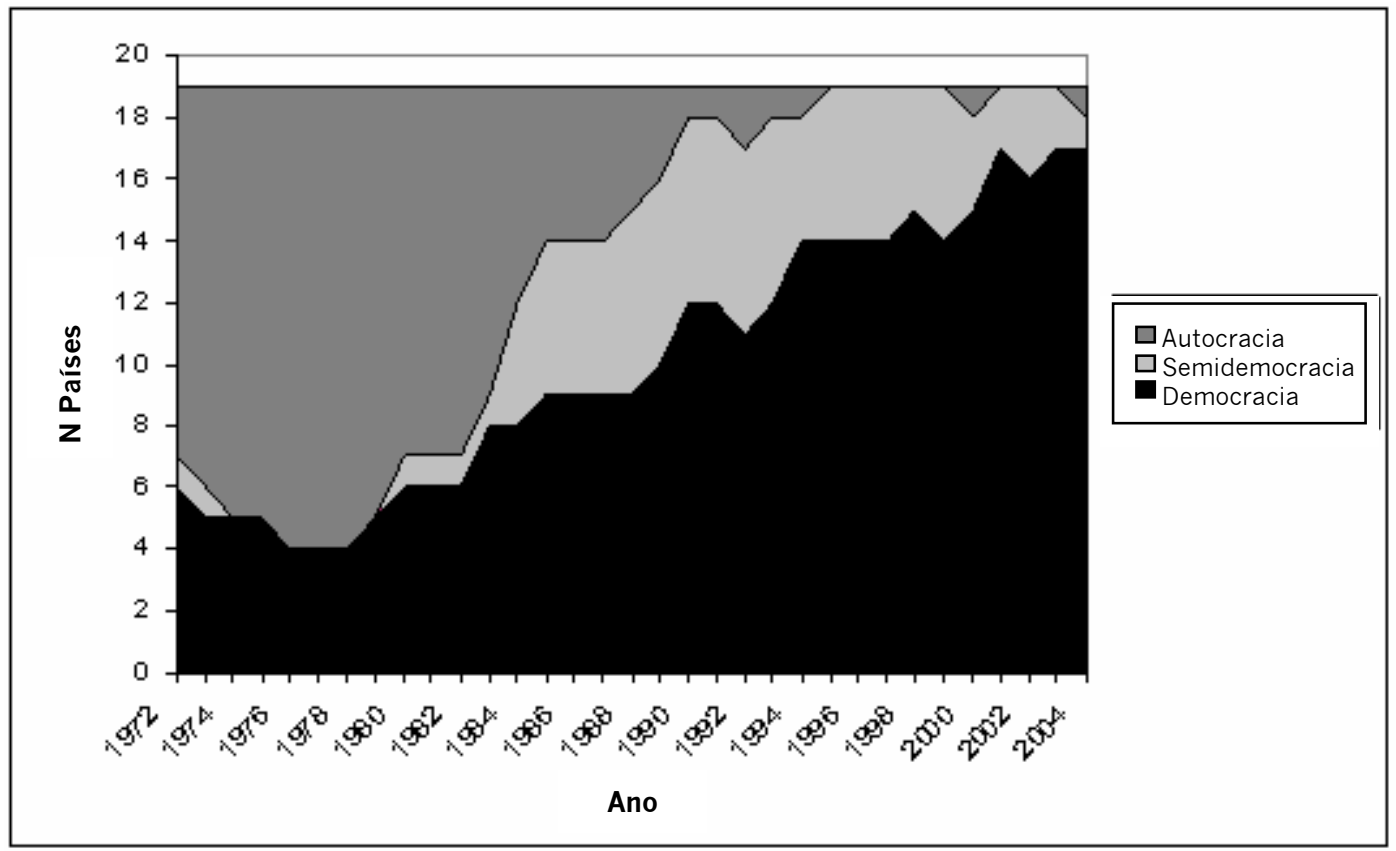

Autocracias plenas desapareceram quase completamente da região. O mesmo ocorreu com a semidemocracia. Na verdade, de meados dos anos 1980 até o final dos 1990, a semidemocracia desempenhou um papel importante como uma "estação no caminho" entre a autocracia e a democracia e, dessa forma, contribui para os processos de transição. Mas, à medida que a democracia eleitoral continuava seu avanço, a semidemocracia saía de cena.

O que se pode dizer da qualidade dessas democracias? Para introduzir essa questão, a Figura 2 expõe, ano a ano para o período 1978-2004, a incidência das democracias liberais e iliberais. Salta aos olhos a expansão da democracia iliberal. 
Em 1980, havia três democracias liberais e três iliberais; em 1990, já eram quatro as liberais e nove as iliberais; no final dos anos 1990, chegou mesmo a haver doze iliberais; e por volta de 2000, eram seis liberais e nove iliberais.

A democracia iliberal tornou-se, assim, a forma mais comum, difundida e visível de organização política na América Latina. Conforme destacamos anteriormente, ela se estendeu por $40 \%$ de todos os países-anos no período considerado. Em 2004, mais de 310 milhões de pessoas (quase $60 \%$ da população total da região) em 10 países estavam vivendo em democracias iliberais. Outros 177 milhões (em sete países) podiam usufruir das benesses da democracia liberal. Somente 20 milhões de latino-americanos, vivendo no Haiti e em Cuba, tinham de tolerar regimes não-democráticos. Não importa o critério - número de países, volume demográfico, países-anos acumulados -, a democracia iliberal emergiu como a modalidade dominante de regime político na região.

Figura 2

Democracias liberal e iliberal na América Latina (1978-2004)

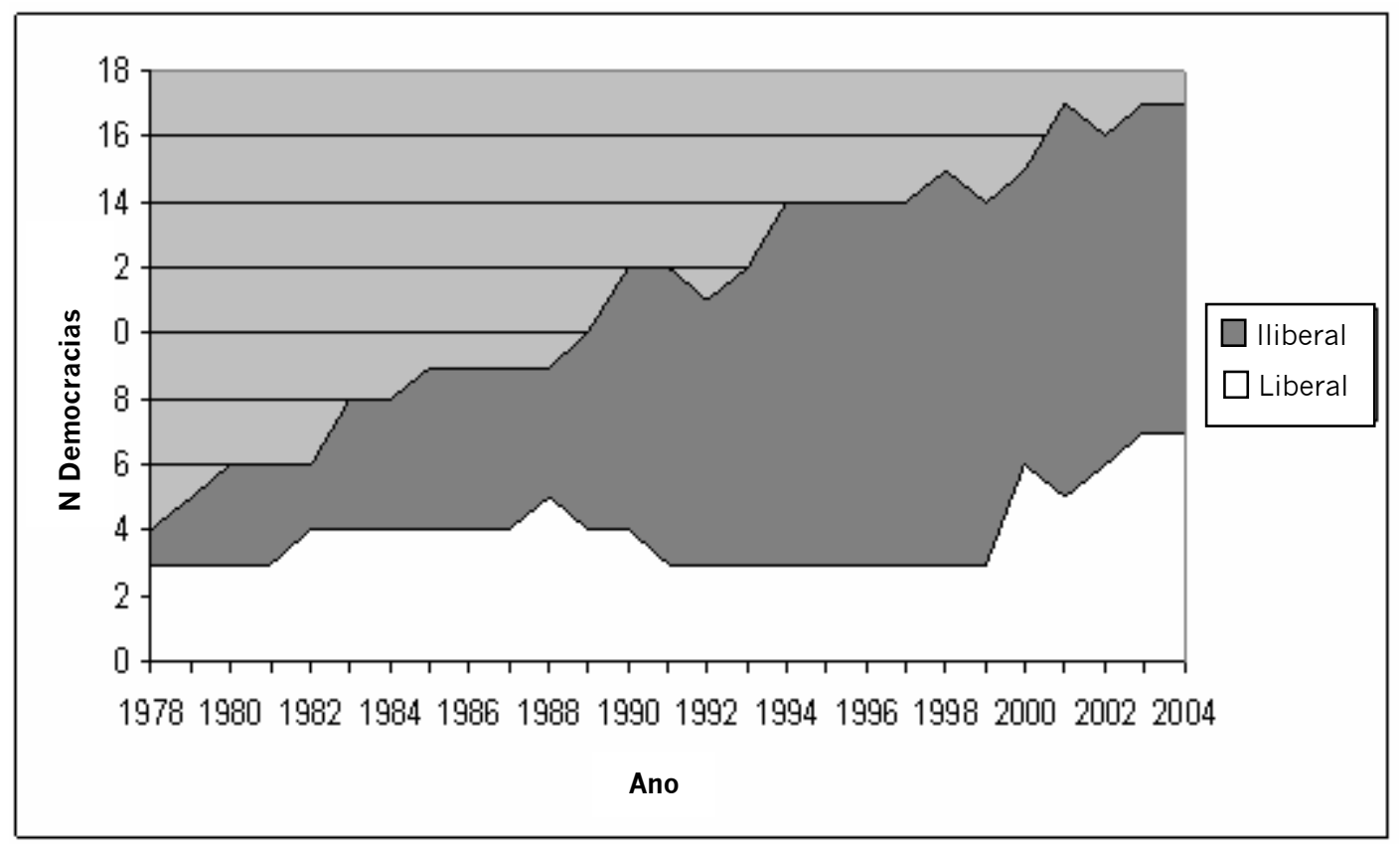

Transições: tipos, ritmos e direções

Seriam os padrões de transição política capazes de revelar caminhos discerníveis que levem de um tipo de regime a outro? Existiriam sendas claras na direção da democracia liberal? 
A Tabela 3 apresenta informações a respeito de cinquenta e seis mudanças de regime entre 1978 e 2004, decompondo os dados por "origem" e "destino" e mostrando o número total de comutações de cada tipo de regime para todos os outros. Para fins de contenção, a tabela combina todas as versões de semidemocracia num só grupo, conjugando igualmente versões linha-dura e moderadas de autoritarismo numa categoria comum de "não-democracia". Das vinte saídas de regimes não-democráticos, por exemplo, doze foram no sentido da semidemocracia, seis no da democracia iliberal e dois no da democracia liberal.

Tabela 3

Transições de regime: origens e destinos, 1978-2004

\begin{tabular}{|c|c|c|}
\hline \multirow[t]{2}{*}{$\mathrm{De}$} & \multicolumn{2}{|c|}{ Para } \\
\hline & Regime & $\mathrm{N}$ \\
\hline \multirow[t]{5}{*}{ Não democracia } & Não democracia & $\cdot$ \\
\hline & Semidemocracia & 12 \\
\hline & Democracia illiberal & 6 \\
\hline & Democracia liberal & 2 \\
\hline & Subtotal & 20 \\
\hline \multirow[t]{5}{*}{ Semidemocracia } & Não democracia & 4 \\
\hline & Semidemocracia & . \\
\hline & Democracia illiberal & 9 \\
\hline & Democracia liberal & 1 \\
\hline & Subtotal & 14 \\
\hline \multirow[t]{5}{*}{ Democracia iliberal } & Não democracia & 2 \\
\hline & Semidemocracia & 3 \\
\hline & Democracia illiberal & - \\
\hline & Democracia liberal & 9 \\
\hline & Subtotal & 14 \\
\hline \multirow[t]{6}{*}{ Democracia liberal } & Não democracia & 0 \\
\hline & Semidemocracia & 0 \\
\hline & Democracia illiberal & 8 \\
\hline & Democracia liberal & $\cdot$ \\
\hline & Subtotal & 8 \\
\hline & Total & 56 \\
\hline
\end{tabular}

Esse rol revela algumas tendências fascinantes. Como já indicado, uma delas é a de que a democracia iliberal provê a via mais comum de saída tanto para não-democracias como para semidemocracias. Somente em raros casos o poder foi cedido pelos autocratas para que democracias plenas se estabelecessem³. É

3 Argentina e Chile representam casos ambíguos, pois anos decisivos de suas transições -1983 e 1990, respectivamente -, são classificados como "democracias iliberais" em decorrência das codificações 
compreensível que preferissem deixar o poder sob a guarda de uma semidemocracia ou de uma democracia iliberal.

Como categoria, a democracia iliberal demonstra considerável tenacidade. Constitui o destino mais frequente, respondendo por nada menos do que vinte e três do total de cinquenta e seis destinos. Entre as quinze democracias iliberais em curso na década de 1990, oito ainda não mostravam sinais de esmorecimento em 2004, além de outras duas que eventualmente voltariam ao conjunto depois de desvios em outras direções ${ }^{4}$. (os casos em questão eram o Equador e o Peru, os mesmos países que haviam dado início ao ciclo todo!) A democracia iliberal não era meramente um ponto de parada nas transições rumo à democracia mais completa; era mesmo um subtipo próprio de regime político.

Ao mesmo tempo, a democracia iliberal poderia representar claramente uma passagem para a democracia liberal: de quatorze saídas, nove foram na direção da democracia liberal (nas outras cinco ocorrências, o governo iliberal recuou para a não-democracia ou para a semidemocracia). Em outras palavras, das doze transições rumo à democracia liberal, nove vieram através da democracia iliberal, somente duas emergiram da não-democracia e uma única da semidemocracia. Nesse sentido, a democracia iliberal operou como um pressuposto comum - nem necessário e nem tampouco suficiente, mas ainda assim recorrente. para a obtenção da democracia liberal.

Essa relação também funcionou inversamente. A democracia liberal foi revertida em democracia iliberal em oito ocasiões, mas nunca - nem sequer uma só vez - abriu caminho para a não-democracia ou para a semidemocracia. Uma implicação faz-se óbvia: o contexto mais seguro para a sobrevivência da democracia liberal é a própria democracia liberal. Outra implicação diz respeito a linhas plausíveis de ação: líderes democráticos poderiam limitar direitos civis com relativa impunidade, mas não seria tão fácil recuar da realização de eleições livres e justas.

Por meio da aritmética básica, a Tabela 3 ainda transmite informações adicionais. Uma delas indica que mudanças de regime são eventos raros. Em meio aos 513 países-anos sob análise, alterações de regime (de qualquer tipo) ocorreram apenas em $10 \%$ do tempo. Transições são menos frequentes do que constumamos pensar; e transições democráticas, como um seu subtipo, têm sido particularmente incomuns. Mudanças em direções democráticas aconteceram em menos de 8\% do total de países-anos, enquanto deslocamentos rumo à democracia liberal tiveram lugar em meros 2,5\% do tempo. Transições de regimes acabaram em democracias liberais em apenas doze dos quarenta e oito casos de transição que partiram de outros pontos (isso é, $25 \%$ do tempo), enquanto a democracia iliberal foi o ponto de

convencionais. Uma reconsideração desses momentos como transições diretas da autocracia para a democracia liberal não afetariam seriamente o resultado geral.

${ }^{4}$ Sem contar o México, que se tornou uma democracia (iliberal) eleitoral em 2000. 
chegada em 55\% das transições potenciais. Sendo assim, a democracia liberal tem sido uma ave rara, sem marcar o fim da maioria das mudanças de regime. Uma implicação adicional é que a democracia plena, em vez de surgir de uma vez, no mais das vezes resulta de um processo paulatino, emergindo passo a passo.

Os dados revelam ainda um ponto adicional: concepções teleológicas das "transições democráticas" correm um risco substancial de erro empírico. De acordo com a Tabela $3,70 \%$ de todos as mudanças de regime seguiram uma direção democrática, enquanto nada menos que $30 \%$ seguiram uma direção nãodemocrática ou autoritária. Houve recuos susbtantivos e repetidos. Pelo menos com respeito à América Latina, não parece haver qualquer razão para assumir que todas as transições acabariam em democracia e nem que iriam nessa direção. Chegou o momento de abandonar o "paradigma da transição" (CAROTHERS, 2002), porque ele simplesmente não corresponde aos fatos.

\section{Correlatos da mudança: em busca das determinantes}

Sob que condições os regimes se movem na direção da democracia plena? Essa questão é abordada por meio de uma análise estatística das transições políticas, destacando, assim, um aspecto de crucial importância para a região: quais são as condições estruturais que facilitam as transições da democracia iliberal à liberal?

\section{Organizando a análise}

Com o propósito de operacionalizar essas preocupações, duas variáveis dependentes dicotômicas foram construídas. A primeira, Totdem, foi codificada com valor 1, aplicável a todas as transições na direção da democracia liberal, incluindo movimentos partindo da não-democracia e da semidemocracia e chegando à democracia eleitoral (liberal ou iliberal) e da democracia iliberal à liberal; nos outros casos, seu valor é zero. Essa variável foi designada para capturar a dinâmica geral da transição e da expansão democráticas. Seus correlatos refletem as condições que levaram os países latino-americanos a expandir o escopo da governança democrática ao longo do último quartel do século XX.

A segunda variável, Ilibalib, enfoca exclusivamente as transições da democracia iliberal à liberal. Foi designada para destacar as condições que levaram as democracias iliberais da região a ampliar ou aprofundar o leque de garantias fundamentais de seus cidadãos. Tomadas em conjunto, essas duas variáveis tornam possível comparar transições na direção da democracia plena, qual quer que tenha 
sido o ponto de partida, com os casos mais restritos das democracias liberais e iliberais ${ }^{5}$.

As variáveis independentes incluem os fatores econômicos e políticos mais frequentemente associados à probabilidade de mudança de regime. De modo a explorar os possíveis efeitos do desenvolvimento socioeconômico, o estudo avaliou os efeitos do PIB, da proporção da força de trabalho empregada na agricultura e dos percentuais de matriculados nas escolas. A pesquisa também criou variáveis dicotômicas por subregião - América Central e Caribe e América do Sul -, levando em conta que a pressão dos Estados Unidos e a ocorrência de guerras civis na década de 1980 podem ter exercido uma influência excepcional sobre os arranjos políticos estabelecidos ao longo de toda a convulsionada área centro-americana. Inobstante seu apelo conceitual, em toda a bateria de testes, nenhuma dessas variáveis revelou quaisquer relações significativas com a mudança de regime ${ }^{6}$.

Seguindo-se a uma extensa experimentação, modelos parcimoniosos foram desenvolvidos, com a seleção cuidadosa de um subconjunto de fatores econômicos e políticos. De início, pressupôs-se que todos os regimes eram favorecidos pela estabilidade e pela prosperidade econômica. Uma das funções primordiais do Estado moderno é proteger seus cidadãos de flutuações financeiras globais através da adoção de prudentes políticas fiscais; quando os regimes são incapazes de controlar a inflação ou encorajar o crescimento econômico, é de se esperar que se debilite sua legitimidade para governar. Tendo isso em mente, a análise avaliou alterações no Produto Interno Bruto (PIBcresc), no PIB per capita (PIBcap) e nas taxas de inflação (Inflação, baseada no deflator inflacionário defasado), no intuito de verificar se esses indicadores econômicos poderiam ajudar a prever mudanças de regime.

Além disso, foi explorado o impacto da revolta social - medida em termos de greves gerais (Greves), revoltas, levantes ou distúrbios (Distúrbios) e manifestações contra o governo (Manifestações). Por um lado, eventos como esses poderiam refletir (ou reforçar) demandas por democracia plena e levar à realização de eleições ou à liberalização do regime. Mas, por outro lado, poderiam também representar sérias ameaças à ordem socioeconômica e encorajar os governantes a reprimir em seus cidadãos ainda mais; ou ainda, poderiam abrir caminho para que atores políticos não-democráticos tomassem as rédeas do governo. Seja como for,

\footnotetext{
5 Uma versão anterior deste artigo também testou as transições de outros tipos: partindo da democracia em outras direções, chegando à democracia liberal de qualquer outro ponto de partida, chegando à democracia iliberal de qualquer outro ponto de partida e transições da democracia liberal à iliberal (SMITH \& ZIEGLER, 2006).

${ }^{6}$ Não foram incluídas outras variáveis por terem sido incompletas as observações, em especial aquelas relativas à taxa de desemprego, à massa salarial do setor público e ao percentual orçamentário destinado a gastos militares.
} 
greves e manifestações parecem servir no mais das vezes para fomentar instabilidade e transformação.

No âmbito da política, geralmente se argumenta que a probabilidade de ocorrência de uma transição democrática depende da existência, da natureza e do alcance de experiências democráticas anteriores. A hipótese de fundo sugere que uma experiência anterior com a democracia reduz a incerteza a respeito do novo regime, refreando, assim, as inquietações de elites enfadadas e precavidas. 0 estudo explorou essa ideia, recorrendo a uma variável que medisse o número simples de experiências prévias com a democracia (Prévias). No mesmo sentido, testou se as democracias são mais ou menos propensas a passar por uma transição quanto maior o período em que estejam no poder, baseando-se na duração da democracia eleitoral (DurDem) como uma medida empírica.

A pesquisa procurou também avaliar se os ciclos eleitorais - eleições presidenciais (Eleição), nesse caso - aumentam a probabilidade de que se produzam mudanças na expansão dos direitos civis. Com a exceção dos regimes mais repressivos, as eleições presidenciais podem oferecer em todos os regimes pontos focais para a mudança política. Candidatos de oposição que defendem o combate à corrupção e uma maior participação dos cidadãos têm incentivos especialmente fortes para cumprir essas promessas (o Anexo 3 apresenta as definições operacionais para todas as variáveis independentes).

Conforme mostra a Tabela 3, a mudança de regime constitui um evento raro. Como são dicotômicas as variáveis dependentes, são as estimativas logit que representam as técnicas mais apropriadas. Dado o reduzido número de anos de transição, erros-padrão logit relativos às variáveis dependentes acabariam sendo distorcidos. Para corrigir esse desvio, os correlatos foram analisados por meio de um Logit de Eventos Raros, doravante referido como Relogit (TOMZ et al, 1999; KING \& ZENG, 2001). As correções do Relogit são particularmente importantes quando quer que o tamanho da amostragem for de 500 ou menos e que a observação do evento (codificado como 1) não ocorrer mais do que $5 \%$ do tempo, sendo que ambas as ressalvas se aplicam no caso desta análise.

\section{Modelando a mudança de regime}

Os resultados básicos figuram na Tabela 4. Enfoquemos aqui a direção das associações (positiva ou negativa) e sua significância estatística, medidas por meio de erros-padrão e valores p (a magnitude dos coeficientes Relogit não produzem uma interpretação significativa). Resultados da "first difference" (ver nota 7) são apresentados para mostrar como o movimento de uma variável altera a probabilidade das transições. 
Uma avaliação superficial revela que as variáveis independentes têm uma força explicativa limitada. Nenhum dos modelos gera previsões suficientemente precisas de transição de regimes $^{7}$. Isso não é inteiramente surpreendente; transições com frequência ocorrem de modo inesperado ou sequer chegam a ocorrer quando acreditamos que deveriam. Mesmo assim, a análises encontrou alguns valores significativos nos modelos e os sinais dos coeficientes foram em sua maioria consistentes com as expectativas.

Tabela 4

Correlatos da democratização: resultados Relogit

\begin{tabular}{|l|l|l|}
\hline & \multicolumn{2}{|c|}{ Variáveis Dependentes } \\
\hline \multicolumn{1}{|c|}{ Variáveis Independentes } & \multicolumn{1}{|c|}{$\begin{array}{c}\text { Transição rumo à democracia } \\
\text { liberal (Totdem) }\end{array}$} & \multicolumn{1}{|c|}{$\begin{array}{c}\text { Transições de iliberal a } \\
\text { liberal (llibalib) }\end{array}$} \\
\hline Variáveis socioeconômicas & \multicolumn{1}{|c|}{} \\
\hline GDPcresc & $.0238(.0342)$ & $.0100(.0499)$ \\
\hline GDP/capita & $.0001(.0001)$ & $.0002(.0002)$ \\
\hline Inflação & $.0002(.0001)^{* * *}$ & $.0016(.0004)^{*}$ \\
\hline Greves & $-.0726(.2705)$ & $.2326(.4097)$ \\
\hline Manifestações & $-.0121(.0951)$ & $.0216(.1359)$ \\
\hline Distúrbios & $.0033(.2420)$ & $.1486(.4642)$ \\
\hline Variáveis políticas & & \\
\hline Prévias & $.1856(.1729)$ & $-.0240(.2869)$ \\
\hline DurDem & $-.0799(.0366)^{* *}$ & $-.0065(.0214)$ \\
\hline Eleição & $1.5392(.4875)^{*}$ & $1.1841(.7417)$ \\
\hline N & 513 & 513 \\
\hline
\end{tabular}

* Significativo no nível .01.

* Significativo no nível 05 .

*** Significativo no nível .10.

Erro-padrão entre parênteses.

O modelo Totdem mostra que a inflação, a duração prévia da experiência democrática e os anos de ocorrência de eleições presidenciais são prognósticos significativos dos movimentos rumo à democracia. Transições de iliberal a liberal democracia estão claramente relacionadas à inflação e, em menor escala, aos anos

7 O programa Relogit não oferece um teste de "goodness of fit" similar ao R2 para o OLS. É possível calcular valores "pseudo-R2", como no Logit, mas isso não é recomendável (recomendação pessoal de Gary King). O modo mais aproximado de calcular o grau de ajuste no Relogit é testar seu valor preditivo a partir do número de transições corretamente previstas. Na regressão logística para eventos raros, "first difference" é uma medida de risco atribuível (KING \& ZENG, 2001). 
de eleição presidencial (com um coeficiente positivo, mas não necessariamente significativo).

Tabela 5

Prognósticos significativos de transições: resultados da diferença primeira

\begin{tabular}{|c|c|c|}
\hline $\begin{array}{c}\text { Variáveis independentes } \\
\text { (valor de saída, valor da } \\
\text { diferença primeira) }\end{array}$ & $\begin{array}{c}\text { Transições rumo a democracia } \\
\text { mais plena (Totdem) }\end{array}$ & $\begin{array}{c}\text { Transições de iliberal a } \\
\text { liberal (Ilibalib) }\end{array}$ \\
\hline $\begin{array}{c}\text { Inflação (valor mediano=16, } \\
\text { Argentina em 1984 = 382) }\end{array}$ & $.03(0 \% \text { to } .07 \%)^{*}$ & $1 \%(.02 \%$ to 3\%) \\
\hline $\begin{array}{c}\text { DurDem (valor mediano = 19, } \\
\text { Costa Rica = 52) }\end{array}$ & $.1 \%(.3 \%$ to $\cdot .1 \%)$ & \\
\hline $\begin{array}{c}\text { Eleição (sem eleição } \\
\text { presidencial = 0, com eleição } \\
\text { presidencial = 1) }\end{array}$ & $15 \%(2 \%$ to $27 \%)$ & \\
\hline
\end{tabular}

Para estimar a força relativa das associações, a Tabela 5 analisa a medida "first difference" para as variáveis socioeconômicas e políticas que revelaram relações estatisticamente significativas com Totdem e Ilibalib. Segundo essa Tabela, os valores identificam, para uma dada mudança em uma das variáveis independentes, quão mais ou menos provável se torna uma transição, todo o resto se mantendo constante no nível mediano. Indicadores econômicos, exceto a inflação, tiveram um baixo desempenho nos modelos. Os indicadores de revolta social tampouco foram significativos, mas suas constantes relações com as variáveis dependentes merecem um exame mais detido. Voltaremos a esse ponto mais adiante.

A expectativa do senso comum seria que a capacidade de qualquer sistema de promover o bem-estar econômico de seus cidadãos deveria estar associada à sua capacidade de manter-se no poder. No geral, essa relação tem sido demonstrada como verdadeira, apesar de a atual onda de democratização guardar diferenças em relação a períodos anteriores de transição (REMMER, 1990; GASIOROWSKI, 1995; SMITH, 2005). Uma análise correlata mostrou que a relação entre o crescimento do PIB e as transições que abandonam a democracia é negativa em um nível estatisticamente significativo: quanto maior o aumento do PIB, menor a incidência de um colapso democrático (SMITH \& ZIEGLER, 2006). Também como mostra a Tabela 4, o crescimento econômico está positivamente associado às transições rumo à democracia mais plena (Totdem) e à expansão dos direitos civis na democracia (Ilibalib), mas essas relações não são estatisticamente significativas. De forma similar, os níveis de desenvolvimento, representados pelo PIB per capita, não guardam qualquer relação observável com nenhuma das duas variáveis de transição. Nem só de pão vivem ou morrem as democracias. 
Assim como para os baixos níveis de crescimento econômico, também se imagina que altas taxas de inflação tenham efeitos desestabilizadores (GASIOROWSKI, 1995; KAUFMAN, 1979; EPSTEIN, 1984). Hiperinflação é a quintessência do choque econômico de curto prazo. É devastadora para os cidadãos, que veem o valor de suas economias despencar e nada além do que um horizonte de incertezas. Ela exacerba a pobreza e a desigualdade, destrói a poupança, desencoraja o investimento e promove a fuga desenfreada de capitais. É particularmente impiedosa com os trabalhadores pobres e com os setores assalariados da classe média, que, compreensivelmente, começam a se questionar sobre a capacidade dos regimes no poder para controlar a economia e protegê-los de flutuações repentinas.

A inflação é um flagelo que assola todos os líderes, comprometendo qualquer que seja o regime que esteja no poder. Cidadãos ultrajados são mais propensos a procurar fazer valer suas demandas econômicas através de protestos de massa, transferindo seu apoio aos partidos de oposição ou clamando por liderança firme e efetiva. Os dirigentes podem reagir de diversas maneiras. Em contextos não-democráticos ou semidemocráticos, podem tentar debelar a insatisfação através de uma modesta alocação de bolsões excepcionais para a expressão do descontentamento e das ansiedades; por outro lado, podem recorrer à repressão, elevando o custo do dissenso em nome da preservação do regime. Sob a democracia iliberal, podem ter de encarar a inquietante mas inevitável perspectiva de convocar eleições livres e justas. Assim, onde quer que o apoio de um regime dependa da garantia de estabilidade econômica, a inflação alta tem boas chances de estimular a transição.

A relação entre inflação e transição - significativa, apesar de fraca, no modelo Totdem - torna-se explícita na análise Ilibalib: quanto mais alta a taxa de inflação, maior a probabilidade de uma expansão dos direitos civis. Mas o vínculo entre espirais inflacionárias e transições da democracia iliberal à liberal é enganosamente modesto quando a taxa de inflação é moderada. A passagem da taxa mediana de inflação a uma taxa alta aumenta a probabilidade de uma transição Ilibalib em apenas $1 \%$. Com a hiperinflação, a história é diferente; em meio aos valores mais altos do deflator inflacionário, a probabilidade estatística da transição varia de 10 a $82 \%$ ! Mesmo que esse resultado seja baseado em um reduzido número de observações, não deixa de ter significância interpretativa persuasiva ${ }^{8}$.

80 valor superior usado na análise da medida "first difference", 382, é o valor deflator inflacionário correspondente à Argentina de 1984. É alto, mas nem chega perto dos valores mais altos da amostra: 12.339 (Bolívia 1985) e 13.611 (Nicarágua 1988). Os valores da medida "first difference" são maiores até mesmo entre valores mais altos na escala média, tais como os da Argentina em 1989 (valor deflator inflacionário de 3.057 ), mas a faixa de predição é consideravelmente grande em meio a esses valores extremos. 
Três variáveis de revolta social foram testadas: greves gerais, manifestações contra o governo e distúrbios. Como dito anteriormente, a associação dessas variáveis com as transições democráticas pode se dar teoricamente em qualquer direção. Os governos podem expandir as liberdades civis para apaziguar os descontentes ou podem também restringi-las e suspender o processo democrático para restaurar a estabilidade interna. Os efeitos opostos das variáveis referentes às greves gerais e às manifestações contra o governo exigem atenção. É possível que dirigente não-democráticos vejam essas formas de protesto como ameaças à segurança pública e respondam por meio de uma maior repressão à liberdade. Essas variáveis independentes de revolta social apresentaram, assim, uma relação negativa, apesar de insignificante, com a transição Totdem no modelo. Em contextos democráticos, por outro lado, greves gerais e manifestações contra o governo (especialmente as mais ordeiras) parecem dar a impressão aos líderes democraticamente eleitos de democracias iliberais de que a repressão seria inefetiva ou contraproducente. Assim, manifestações contra o governo e greves gerais guardam uma relação positiva com as transições da democracia iliberal à liberal (llibalib). O protesto social mais desestabilizador de todos, as revoltas, levantes ou distúrbios, têm uma relação positiva com ambas as variáveis dependentes. Esses resultados sugerem, porém, que se empreguem com cautela variáveis agregadas de "distúrbio social" para a análise da mudança política.

Como mostra a Tabela 5, a variação de duração DurDem apresenta um coeficiente significativo e negativo no modelo Totdem (esse argumento pode parecer à primeira vista tautológico, mas não em vista do número e da frequência das transições observadas). Uma mudança na variável da subsistência da democracia eleitoral (Durdem) do valor mediano de 19 anos para o valor de 52 anos (da Costa Rica de 2004) reduziria a probabilidade de uma transição para uma democracia mais plena em 1\%. Uma constatação como essa oferece certa evidência à ideia de "consolidação" do regime; quanto mais durar um regime, seja ele democrático ou autoritário, menor é sua propensão à transição. Estudos anteriores comprovaram não haver relação verificável entre a duração da democracia e a propensão à transição (PRZEWORSKI et al, 1996). Ainda que os resultados dificilmente sejam conclusivos, sugerem que a inércia ou o "momento" do regime podem fazer da mudança algo menos provável. Por outro lado, os resultados não produziram qualquer evidência que confirmasse a ideia de que uma experiência prévia (Prévias) aumenta a probabilidade de uma democracia mais plena.

Os resultados da variável da eleição presidencial são robustos para transições rumo à democracia mais plena. Sua relação com Totdem é positiva e estatisticamente significativa no nível .01. Como argumentou-se anteriormente, campanhas presidenciais podem levar a avanços subsequentes nos graus de prática democrática. Casos marcantes de eleições cruciais coincidiram com o colapso de 
regimes autoritários no Equador em 1979, no Uruguai em 1985 e no Chile em 1989. Outras eleições decisivas ocorreram na Argentina em 1989 e 2003, no Brazil em 1989, na Guatemala em 1995, em Honduras em 1981, no México em 2000 e na Nicarágua em 1990 .

A força das relações entre o ano de eleição presidencial e as variáveis da transição emerge com considerável clareza. Se todos os outros fatores mantiverem. se constantes, os Estados têm uma propensão $15 \%$ maior a passar por uma transição rumo à democracia (não necessariamente conducente à democracia liberal, mas ao menos melhorando sua posição na escala) em um ano em que há eleição presidencial do que em um ano fora do ciclo eleitoral. Esse é o resultado mais forte entre todos os do modelo Totdem. Essa relação é positiva (e virtualmente significativa) também para as transições Ilibalib, com um aumento previsto de $3 \%$ nas chances de uma transformação na direção da democracia liberal.

Foi argumentado aqui que altas taxas de inflação favorecem transições da democracia iliberal à liberal. Podemos inferir que altos níveis de inflação exercem pressão sobre as democracias iliberais, com frequência provocando formas ordeiras de protesto tais como greves gerais, e que a reação a tais demandas populares frequentemente consiste em um relaxamento dos controles impostos pelo Estado, o que, por definição, representa uma expansão dos direitos civis. Essa, por sua vez, pode ajudar a explicar a coincidência entre os ciclos eleitorais e as passagens de democracias iliberais a liberais. A maior parte dessas transições ocorreu próxima ao período de eleições nacionais: Argentina em 1983.4 e 2000, Equador em 1988, República Dominicana em 1982 e 2000, Chile em 1989.90 e Panamá em 1999. $2000^{10}$. Além desses casos, há o do México, onde Vicente Fox não precisou de mais do que um ano para levar o país à democracia liberal. Um traço marcante de todas essas eleições é que levaram à vitória a oposição política: vêm à mente não apenas Alfonsín, Aylwin e Fox, mas também Fernando de la Rúa, Rodrigo Borja, Leonel Fernández Reyna e mesmo Mireya Moscoso. Baseando-se em plataformas que desafiavam os regimes (iliberais) no poder, os candidatos oposicionistas foram obrigados e cumprir suas promessas de campanha e estender as garantias de liberdade de expressão, de imprensa, de assembleia - e promover a imparcialidade do estado de direito. Ademais, esse tipo de reforma política acarreta mais do que meros ônus de curto prazo: é muito mais fácil suspender limitações ao dissenso do

\footnotetext{
${ }^{9}$ Em alguns casos, a transição ocorreru no ano seguinte à eleição presidencial. Uma versão defasada da variável da eleição presidencial produz relações estatisticamente significativas tanto com Totdem como com Ilibalib, enfatizando assim a importância do fenômeno eleitoral. Ela tem, porém, a desvantagem de reduzir a significância da variável da inflação, que é essencial para a interpretação mais ampla oferecida neste estudo.

10 Argentina e Chile foram casos especiais, porque seus períodos de "democracia iliberal" em 1983 e 1989 foram antes períodos de transição política que se estenderam por cerca de um ano do que propriamente regimes iliberais estabelecidos (ver nota 3).
} 
que os impor (no longo prazo, o debate público e a transparência podem dificultar a reeleição do detentor do cargo e de seu partido, mas isso corresponde a outro tema). Um aspecto, porém, parece surpreendemente claro: eleições e liderança são capazes de realizar mudanças de peso na vida política dos cidadãos. Em poucas palavras, eleições livres e justas são o calcanhar de Aquiles das democracias iliberais.

\section{Conclusões}

Ao longo da "terceira onda", a mudança política na América Latina se deu em meio a um cenário marcado por um traço distintivo: tratava-se de uma era de democracia iliberal. Em quase todos os lugares, a combinação de eleições livres e justas com uma repressão parcial mas sistemática dos direitos civis tornou-se uma marca predominante e decisiva. De acordo com uma ampla série de indicadores número de países, massa populacional, percentual de países-anos -, a democracia iliberal reinou incontrastável. É certo que a democracia liberal ganhou terreno nos anos recentes, mas não há razão inegável para acreditar que será capaz de ocupar o lugar da democracia iliberal num futuro próximo.

Mudanças de regime são momento de máxima incerteza. Os dados deste artigo mostram que pressuposições teleológicas a respeito da direção "democrática" das mudanças de regime são completamente infundadas. Pelo menos desde o final dos anos 1970, a maioria das transições de regime conduziu a algo distinto da democracia liberal. O destino mais comum foi a democracia iliberal. Ao mesmo tempo em que esta ajudou a abrir o caminho para a democracia liberal, um bom número de retrocessos também ocorreu. Mesmo após longos períodos no poder, conforme revelam os dados quantitativos, a democracia liberal frequentemente sucumbiu diante da democracia iliberal.

O que é capaz de trazer a democracia liberal à tona? Essa análise revelou que as correlações entre transições rumo à democracia liberal e um leque de variáveis independentes - das variações do PIB às manifestações contra o governo não satisfazem requisitos mínimos de significância estatística. Esses não-resultados são, porém, muito significativos, uma vez que nos permitem excluir - e descartar . uma série ampla de hipóteses aparentemente plausíveis. Este artigo serviu, portanto, para limpar o terreno.

Comprovou-se que a determinante estrutural de maior destaque na transição da democracia iliberal à liberal foram as altas taxas de inflação. A interpretação deste artigo indica que, sob a democracia iliberal, os cidadãos estão dispostos a aceitar limitações ao dissenso em troca da promessa de segurança econômica. Mas em decorrência de sua natureza, as espirais inflacionárias rompem esse tácito acordo semi-autoritário. Os protestos se multiplicam e a pressão aumenta. 
Distúrbios sociais assombram a mente de todos os dirigentes. Políticos de todos os matizes prefeririam evitar manisfestações contra o governo e greves políticas; elas representam manifestações inegáveis de fracasso do regime e podem acarretar enormes consequências econômicas. A análise aqui proposta demonstra que esse comportamento social pode ter um considerável impacto político. Sob um governo autoritário, qualquer tipo de democratização se torna menos provável ao se realizarem greves gerais e manifestações contra o governo. Entretanto, quando eleições livres e justas são realizadas, a expansão dos direitos civis é mais provável quando os cidadãos a expressam suas demandas econômicas e políticas. A constatação desses efeitos diferenciados da mobilização popular neste artigo representa uma contribuição significativa para a literatura acadêmica que trata de transições democráticas.

Em democracias iliberais, os cidadãos podem votar em lideranças e partidos da oposição. E, uma vez no poder, os dirigentes recém-eleitos podem suspender as limitações às garantias fundamentais. Essa combinação de ativismo de base com oportunidade eleitoral e substituição de elites políticas abre o caminho que leva à democracia liberal. Nesse cenário, a conquista da democracia plena depende de três fatores: a força da sociedade civil, a disponibilidade dos canais de expressão e a predisposição da liderança política, especialmente no nível presidencial.

Desenvolvimentos nesse sentido desnudam as contradições internas de regimes iliberais: a tensão inerente entre a liberdade das eleições e as restrições à expressão. Esse paradoxo define o fulcro da política contemporânea na América Latina. Como tão frequentemente ocorre, uma tal inconsistência lógica não exige necessariamente uma solução efetiva. Ela representa a pedra-de-toque do processo de transição democrática e poderá mesmo persistir nesse papel no futuro.

\section{Referências Bibliográficas}

BANCO MUNDIAL. World Development Indicators Database 2004. Washington, DC: Banco Mundial. Disponível em: <http://devdata.worldbank.org/dataonline>, 2004.

BANKS, A. Cross-National Time-Series Data Archive. Databanks International. Disponível em: <www.databanks.sitehosting.net/Default.htm>, 2006.

CAROTHERS, T. "The End of the Transition Paradigm". Journal of Democracy, v.13, $n^{\circ} 1,2006$. 
CINGRANELLE, D. L. e RICHARDS, D. L. "Measuring the Level, Pattern, and Sequence of Government Respect for Human Rights". International Studies Quarterly, v.43, n² 2,1999

COLLIER, D. e LEVITSKY, S. "Democracy with Adjectives: Conceptual Innovation in Comparative Research". World Politics, v.49, n 3, 1997.

DAHL, R. A. Polyarchy: Participation and Opposition. New Haven: Yale University Press, 1971.

DIAMOND, L. Developing Democracy: Toward Consolidation. Baltimore: The Johns Hopkins University Press, 1999.

DIAMOND, L. e MORLINO, L. (orgs.). Assessing the Quality of Democracy. Baltimore: Johns Hopkins University Press, 2005.

EPSTEIN, E. "Legitimacy, Institutionalization, and Opposition in Exclusionary Bureaucratic Authoritarian Regimes". Comparative Politics, n 17, 1984.

GASIOROWSKI, M. J. "Economic Crisis and Political Regime Change: An Event History Analysis". American Political Science Review, v.89, n 4, 1995.

HAGOPIAN, F. e MAINWARING, S. (orgs.). The Third Wave of Democratization in Latin America: Advances and Setbacks. Cambridge: Cambridge University Press, 2005.

KAUFMAN, R. Industrial Change and Authoritarian Rule in Latin America: A Concrete Review of the Bureaucratic Authoritarian Model. In: COLLIER, D. (org.). New Authoritarianism in Latin America. Princeton: Princeton University Press, 1979.

KING, G. e ZENG, L. "Logistic Regression in Rare Events Data". Political Analysis, v. 9, $\mathrm{n}^{\circ} 2,2001$

LUSTIG, N. (org.). Coping with Austerity: Poverty and Inequality in Latin America. Washington DC: Brookings Institution, 1995.

MAINWARING, S. e PÉREZ-LIÑÁN, A. Latin American Democratization Since 1978: Democratic Transitions, Breakdowns, and Erosions. In: HAGOPIAN, F. e MAINWARING, S. (orgs.). The Third Wave of Democratization in Latin America: Advances and Setbacks. Cambridge: Cambridge University Press, 2005.

MAINWARING, S. e SCULLY, T. R. (orgs.). Building Democratic Institutions: Party Systems in Latin America. Stanford: Stanford University Press, 1995.

O’DONNELL, G. "Delegative Democracy”. Journal of Democracy, v. 5, nº 1 Jan., 1994. 
O'DONNELL, G.; CULLELL, J. V. e IAZZATTA, O. M. (orgs.). The Quality of Democracy: Theory and Applications. Notre Dame: Notre Dame University Press, 2004.

PRZEWORSKI, A. Democracy and Development: Political Institutions and Well-Being in the World, 1950-1990. Cambridge: Cambridge University Press, 2000.

PRZEWORSKI, A.; ALVAREZ, M.; CHEIBUB, J. e LIMONGI, F. "What Makes Democracies Endure?". Journal of Democracy, v. 7, n 1, 1996.

REMMER, K. Debt or Democracy? The Political Impact of the Debt Crisis in Latin America. In: FELIX, D. (org.). Debt and Transfiguration? Prospects for Latin America's Economic Revival. Armonk, NY: Sharp, 1990.

SCHEDLER, A. "Elections without Democracy: The Menu of Manipulation". Journal of Democracy, v.13, $\mathrm{n}^{\circ} 1,2002$.

(org.). Electoral Authoritarianism: The Dynamics of Unfree Competition. Boulder: Lynne Rienner Publishers, 2006.

SMITH, P. H. "Los ciclos de democracia electoral en América Latina, 1900-2000". Política y Gobierno , v.11, $n^{\circ}$ 2, 2004.

Democracy in Latin America: Political Change in Comparative Perspective. New York: Oxford University Press, 2005.

SMITH, P. H. E ZIEGLER, M. Illiberal and Liberal Democracy in Latin America. Trabalho apresentado ao 26o. Congresso Internacional da Associação de Estudos LatinoAmericanos, San Juan, Porto Rico, março de 2006.

TOMZ, M.; Gary K. e Langche Z. "ReLogit: Rare Events Logistic Regression”. Stata Version, v.1, n 1.29 de outubro, 1999.

U.S. STATE DEPARTMENT. Country Reports on Human Rights Practices. Washington, DC: U.S. Government Printing Office.

ZAKARIA, F. "The Rise of Illiberal Democracy". Foreign Affairs, v.76, n 6 nov./dez, 1997. 


\section{Anexo 1 \\ Classificação e medição}

O propósito deste artigo é aplicar a ideia de "democracia iliberal" de Fareed Zakaria às realidades políticas da América Latina contemporânea e ver o que podemos aprender com esse experimento. Em busca desse objetivo, o estudo oferece meios para aperfeiçoar os próprios método que Zakaria empregou para a medição empírica ${ }^{11}$. Procura "desempacotar" o conceito de democracia e explorar a interação entre suas partes constitutivas. Tomando de empréstimo uma frase de Przeworski et al, a associação entre essas facetas da democracia "deve estar aberta à investigação e não fechada por uma definição" (PRZEWORSKI et al, 2000, p.33. 34). Por isso, escalas compostas dos graus de democracia, tais como POLITY IV, não tiveram utilidade em nosso empreendimento.

\section{Democracia eleitoral}

Esta análise parte de uma definição rigorosamente minimalista de democracia eleitoral. Eleições são consideradas "democráticas" se forem livres e justas: se o sufrágio adulto for mais ou menos universal, se for permitido a todos os candidatos sérios concorrer, se qualquer dos candidatos tiver chance de vencer, se os votos forem apurados corretamente, se a vitória for concedida ao candidato com o maior número de votos (de acordo com regras transparentes para a decisão do pleito) e se o candidato vencedor obtiver autoridade efetiva em decorrência de sua vitória.

Cada um dos anos, de 1978 a 2004, para cada um dos dezenove países latino-americanos, foi codificado segundo esses critérios. A categorização baseou-se em juízos qualitativos derivados de observação direta, fontes secundárias, relatórios de imprensa e consultas aprofundadas junto a colegas acadêmicos. Foram igualmente avaliados dados quantitativos referentes ao registro de eleitores, comparecimento às urnas e margens de diferença relativas à votação do candidato vitorioso. Foram encontrados inúmeros casos de eleições formais (com frequência consideradas "democráticas") que satisfizeram alguns critérios, mas não todos. Assim, as eleições foram consideradas semidemocráticas em casos nos quais:

- apenas um candidato tinha chances reais de vitória - como no México (1988-99), no Peru (1993-2000) e na Venezuela (1999-2004);

- obstáculos foram interpostos a algumas candidaturas - como no Brasil (1985.89) e na Argentina (2002);

\footnotetext{
11 Zakaria considera todos os países com pontuações Freedom House conjugadas entre 5 e 10 como países "em democratização" e todos os casos nos quais a pontuação para "direitos políticos" é maior do que a de "direitos civis" como "democracias iliberais". Isso significa que um país com 4 pontos em direitos políticos e $5 \mathrm{em}$ direitos civis seria classificado como uma democracia iliberal. Este artigo, porém, insiste que um país deve realizar eleições genuinamente livres e justas para que possa ser considerado uma democracia, liberal ou iliberal.
} 
- $\quad$ as forças armadas detinham o poder real - como em El Salvador (1984-93), Guatemala (1986-95) e Honduras (1981-96);

- $\quad$ uma força estrangeira exercia influência indevida - como no Panamá (1990. 93).

Essas subcategorias diferenciam-se analiticamente umas das outras. Em princípio, mereceriam codificações específicas; mas, na prática, tendem a sobreporse. Apesar de sua ocorrência não ter sido relativamente tão frequente, todas foram agrupadas sob uma rubrica única de semidemocracia.

O início de períodos "democráticos" ou "semidemocráticos" foi codificado de acordo com o ano da realização do primeiro pleito presidencial. A nãodemocracia permaneceu como uma categoria residual, exceto para o anos correspondentes a golpes militares, que foram codificados categoricamente como não-democráticos. Também os anos correspondentes à ocupação por forças estrangeiras (p.ex., Haiti 2004) foram codificados como não-democráticos.

\section{Direitos civis}

A segunda tarefa consistiu em obter um indicador aplicável aos direitos dos cidadãos. Depois de várias tentativas e erros, foi construída uma variável composta. O primeiro passo foi consultar os relatórios anuais da Freedom House (FH) sobre "direitos civis", que verificam a presença de "direitos para desenvolver visões, instituições e autonomia pessoal independentes em relação àquelas promovidas pelo estado". A lista de critérios da FH inclui itens tais como:

- $\quad$ liberdade de expressão e crença, incluindo liberdade de imprensa;

- $\quad$ direito de assembleia, associação e organização;

- $\quad$ imparcialidade da justiça e proteção dos direitos humanos;

- autonomia pessoal e direitos econômicos, incluindo a livre escolha do local de residência e da ocupação.

Esse rol cobre um espectro extremamente amplo e inclui alguns fenômenos (tais como emprego ilegítimo da força militar ou servidão econômica) que não necessariamente refletem os desígnios, intenções ou capacidades das autoridades estatais.

Através da avaliação de especialistas, os países recebem pontuações que vão de 1 (maior amplitude de direitos) a 7 (direitos virtualmente inexistentes). As pontuações da FH representam, assim, juízos momentâneos feitos por observadores bem-informados e de boa fé. O próprio Zakaria apoiou-se nas medições da FH em seu artigo original.

Como observam estudiosos do tema, os indicadores da Freedom House para "direitos civis" tendem a apresentar intensas correlações com medições distintas da FH relativas aos "direitos políticos". No interior de nosso quadro de países-anos latino-americanos, por exemplo, o coeficiente de correlação $r$ de Pearson para as escalas de sete pontos alcança +.821 . Não chega a ser surpreendente que essa relação seja positiva. De fato, esse aspecto opera em nosso favor, porque a noção de "democracia iliberal" remete a limitações impostas não apenas aos direitos civis, mas também aos "direitos políticos" - livre participação no processo político, 
expressão irrestrita de opiniões políticas, direito de participar de agremiações políticas, etc ${ }^{12}$.

Dada a amplitude da definição da $\mathrm{FH}$, as pontuações foram reduzidas a três categorias:

- pontuações de 1 a 2 indicam direitos civis "amplos", correspondentes a unidades políticas liberais;

- de 3 a 4 refletem direitos civis "moderados", típicos de sistemas iliberais;

- de 5 a 7 revelam direitos "mínimos" ou inexistentes, caracterizando regimes repressivos ${ }^{13}$.

Contrariamente ao seu uso convencional, decidimos deliberadamente mover nossa medição de um nível mais alto para um mais baixo. Isso foi feito por razões tanto técnicas como conceituais. De saída, a noção de direitos civis foi construída como uma variável ordinal-nominal com três pontos.

O segundo passo foi verificar a validade da variável baseada nos indicadores da $\mathrm{FH}$ em relação ao banco de dados Cingranelli-Richards (CIRI) recentemente estabelecido e que abrange unidades políticas de todo o mundo de 1980 até o presente. Esse exercício enfocou duas medidas compostas: o índice CIRI de "integridade física" (de 0 a 8, do pior ao melhor), baseado em medições quantitativas de aprisionamento político, tortura, desaparecimentos e execuções extrajudiciais; e um índice de "direitos empoderadores" (de 0 a 10, do pior ao melhor), baseado em medições quantitativas da liberdade de movimento e expressão, direitos trabalhistas, participação política e liberdade religiosa (CINGRANELLI \& RICHARDS, 1999). A preocupação aqui era bastante clara: em que medida são comparáveis as medições de direitos civis da Freedom House e as dos indicadores CIRI?

Eles mostraram ser bastante próximos. A correlação entre a escala FH de 7 pontos de direitos civis e a escala CIRI de 8 pontos de integridade física chega a +.554 (com uma escala invertida); a correlação com os direitos empoderadores é de +.588. É interessante que ambas as correlações sejam mais altas que a associação entre as duas medições CIRI, que alcançam, para os casos tratados neste artigo, uma marca de +.343. A variável $\mathrm{FH}$ de direitos civis ocupa um espectro médio entre as duas escalas CIRI e, portanto, representa uma base válida para oferecer um indicador omnibus de tudo aquilo que neste artigo chamamos de direitos civis.

Como um teste adicional, os dados CIRI foram reduzidos a uma escala de três pontos e os resultados cruzados com o indicador FH de três pontos. As Tabelas 6 e 7 expõem os resultados.

\footnotetext{
12 A medição de direitos políticos da $\mathrm{FH}$, porém, não foi diretamente utilizada, pois engloba o processo eleitoral, que foi pontuado de acordo com uma escala própria, definida e explicada ao longo deste artigo. $13 \mathrm{Na}$ verdade, esses são intervalos equivalentes, pois a pontuação 7 pontos da $\mathrm{FH}$ foi registrada em apenas 3 países-anos em meio aos 513 avaliados aqui (todos referentes ao Haiti sob Cédras).
} 
Tabela 6

Direitos civis FH e Índice de integridade física CIRI $(\mathrm{N}=456)$

\begin{tabular}{|c|c|c|c|}
\hline \multirow[b]{2}{*}{ Pontuação FH } & \multicolumn{3}{|c|}{ Pontuação CIRI } \\
\hline & Baixa (0.2) & Média (3.5) & Alta (6.8) \\
\hline Mínima (5.7) & 33 & 38 & 2 \\
\hline Moderada (3.4) & 77 & 145 & 54 \\
\hline Ampla (1-2) & 2 & 38 & 67 \\
\hline
\end{tabular}

Tabela 7

Direitos civis FH e Índice de direitos empoderadores CIRI $(\mathrm{N}=455)$

\begin{tabular}{|l|l|l|l|}
\hline & \multicolumn{3}{|l|}{ Pontuação CIRI } \\
\hline Pontuação FH & Baixa (0-3) & Média (4-7) & Alta (8-10) \\
\hline Mínima (5-7) & 13 & 52 & 7 \\
\hline Moderada (3-4) & 5 & 79 & 194 \\
\hline Ampla (1-2) & 0 & 13 & 92 \\
\hline
\end{tabular}

A correspondência é bastante próxima. Os coeficientes gamma das duas tabelas são quase idênticos: +.689 para a integridade física e +.685 para o empoderamento pessoal. De igual importância é o fato de que muito poucas observações (4 para a integridade física e 7 para o empoderamento pessoal) encontram-se em células opostas (ampla-baixa e mínima-alta). Essas discrepâncias foram exploradas cuidadosamente e, no caso dos países-anos selecionados, ajustes adequados foram feitos nas pontuações relativas aos direitos civis ${ }^{14}$.

Como terceiro e último passo, a noção de direitos civis foi amparada com evidência qualitativa oriunda de duas fontes adicionais: a publicação anual do Comitê para a Proteção dos Jornalistas, Attacks on the Press, e os relatórios por país do Departamento de Estado dos Estados Unidos sobre as práticas de direitos humanos. Cabe destacar que os relatórios anuais da FH contêm também um sumário descritivo dos eventos e tendências que poderiam precipitar uma mudança de uma categoria de direitos civis para outra: libertação de prisioneiros políticos, suspensão de leis de censura, legalização de sindicatos, cassação de juízes corruptos, permissão de manisfestações, e por aí afora. Essa documentação provou ser essencial tanto para confirmar a validade da escala de direitos civis quanto para

14 Tais discrepâncias tendem a resultar em uma variação acentuada entre as medições CIRI. Na Tabela 6, por exemplo, Paraguai 1988 recebeu uma pontuação positiva para a integridade física - dada a frequência relativamente baixa de tortura e desaparecimentos, sendo a razão para a inconsistência diante da pontuação FH - juntamente com uma pontuação baixa no empoderamento. Na Tabela 7, Peru 1991 pontuou bem no índice de empoderamento, mas muito mal na integridade física, dada a violência da campanha empreendida pelo Estado contra o Sendero Luminoso. Em nossa avaliação, esses resultados marginais oferecem prova adicional de que uma medição composta, baseada nas pontuações FH para direitos civis, representam um mecanismo apropriado de medição dos direitos civis. 
lançar luz empírica sobre o sentido prático da democracia iliberal (SMITH, 2005, cap. 10).

Com a confiança reforçada por esses testes, a análise foi conduzida adiante. Contudo, um inconveniente inevitável persistiu, pois os procedimentos de codificação nem sempre alcançam uma sincronização perfeita: avaliações da democracia eleitoral são baseadas em observações qualitativas de eventos periódicos ocorridos em curtos períodos de tempo, enquanto as avaliações dos direitos civis baseiam-se em relatos anuais de processos cumulativos que se estendem ao longo de anos. Mudanças nas pontuações eleitorais podem ser claramente remetidas a ocorrências específicas (p.ex., eleições); mudanças relativas aos direitos civis, por outro lado, acontecerão em decorrência de alterações graduais nas condições objetivas do ambiente político (p.ex., tolerância das forças de oposição). Essa disjunção pode causar "soluços" aparentes e inconsistências na codificação. Ainda assim, são bem pouco frequentes e não chegam a distorcer os resultados gerais.

\section{Anexo 2}

Regime político por país, 1978-2004

\begin{tabular}{|l|l|}
\hline \multicolumn{2}{|l|}{ Argentina } \\
\hline $1978-1980$ & não-democracia linha dura \\
\hline $1981 \cdot 1982$ & não-democracia moderada \\
\hline 1983 & democracia iliberal \\
\hline $1984-1989$ & democracia liberal \\
\hline $1990 \cdot 2000$ & democracia iliberal \\
\hline 2000 & democracia liberal \\
\hline 2001 & democracia iliberal \\
\hline 2002 & semidemocracia iliberal \\
\hline $2003 \cdot 2004$ & Democracia liberal \\
\hline
\end{tabular}

\begin{tabular}{|l|l|}
\hline \multicolumn{2}{|c|}{ Bolívia } \\
\hline $1978-1979$ & não-democracia moderada \\
\hline 1980 & não-democracia linha dura \\
\hline $1981 \cdot 1982$ & não-democracia moderada \\
\hline $1983 \cdot 2004$ & democracia iliberal \\
\hline
\end{tabular}

\begin{tabular}{|l|l|}
\hline \multicolumn{2}{|c|}{ Brasil } \\
\hline $1978 \cdot 1984$ & não-democracia moderada \\
\hline $1985 \cdot 1987$ & semidemocracia liberal \\
\hline 1988 & semidemocracia iliberal \\
\hline 1989 & semidemocracia liberal \\
\hline $1990 \cdot 2004$ & democracia iliberal \\
\hline
\end{tabular}

\begin{tabular}{|l|l|}
\hline \multicolumn{2}{|c|}{ Chile } \\
\hline $1978-1987$ & não-democracia linha dura \\
\hline 1988 & não-democracia moderada \\
\hline 1989 & democracia iliberal \\
\hline $1990-2004$ & democracia liberal \\
\hline
\end{tabular}

\begin{tabular}{|c|c|}
\hline \multicolumn{2}{|r|}{ Colômbia } \\
\hline 1978.2004 & democracia iliberal \\
\hline \multicolumn{2}{|r|}{ Costa Rica } \\
\hline 1978.2004 & democracia liberal \\
\hline \multicolumn{2}{|r|}{ Equador } \\
\hline 1978 & não-democracia moderada \\
\hline 1979.1984 & democracia liberal \\
\hline 1985-1987 & democracia iliberal \\
\hline $1988-1990$ & democracia liberal \\
\hline 1991.1995 & democracia iliberal \\
\hline 1996.1999 & semidemocracia iliberal \\
\hline 2000 & não-democracia moderada \\
\hline $2001 \cdot 2004$ & democracia iliberal \\
\hline \multicolumn{2}{|r|}{ El Salvador } \\
\hline 1978 & não-democracia linha dura \\
\hline 1979 & não-democracia moderada \\
\hline 1980 & semidemocracia iliberal \\
\hline $1981 \cdot 1983$ & não-democracia linha dura \\
\hline 1984 & semidemocracia repressiva \\
\hline $1985 \cdot 1993$ & semidemocracia iliberal \\
\hline 1994.2004 & Democracia iliberal \\
\hline
\end{tabular}


SMITH, P.; ZIEGLER, M. Democracias liberal e iliberal na América Latina

\begin{tabular}{|l|l|}
\hline \multicolumn{2}{|c|}{ Guatemala } \\
\hline 1978 & não-democracia moderada \\
\hline $1979 \cdot 1984$ & não-democracia linha dura \\
\hline 1985 & não-democracia moderada \\
\hline $1986 \cdot 1990$ & semidemocracia iliberal \\
\hline $1991 \cdot 1995$ & semidemocracia repressiva \\
\hline $1996 \cdot 2004$ & Democracia iliberal \\
\hline
\end{tabular}

\section{Haiti}

\begin{tabular}{|l|l|}
\hline \multicolumn{2}{|c|}{ Haiti } \\
\hline $1978-1985$ & não-democracia linha dura \\
\hline 1986 & não-democracia moderada \\
\hline $1987-1989$ & não-democracia linha dura \\
\hline 1990 & democracia iliberal \\
\hline $1991 \cdot 1994$ & não-democracia linha dura \\
\hline $1995 \cdot 2003$ & semidemocracia repressiva \\
\hline 2004 & não-democracia linha dura \\
\hline
\end{tabular}

\begin{tabular}{|l|l|}
\hline \multicolumn{2}{|l|}{ Honduras } \\
\hline $1978-1980$ & não-democracia moderada \\
\hline $1981 \cdot 1996$ & semidemocracia iliberal \\
\hline $1997-2004$ & democracia iliberal \\
\hline
\end{tabular}

\section{México}

\begin{tabular}{|l|l|}
\hline \multicolumn{2}{|c|}{ México } \\
\hline $1978 \cdot 1987$ & não-democracia moderada \\
\hline $1988 \cdot 1999$ & semidemocracia iliberal \\
\hline $2000 \cdot 2001$ & democracia iliberal \\
\hline $2002 \cdot 2004$ & democracia liberal \\
\hline
\end{tabular}

\begin{tabular}{|l|l|}
\hline \multicolumn{2}{|l|}{ Nicarágua } \\
\hline $1978-1983$ & não-democracia linha dura \\
\hline $1984-1987$ & semidemocracia repressiva \\
\hline 1988 & semidemocracia iliberal \\
\hline 1989 & semidemocracia repressiva \\
\hline $1990-2004$ & semidemocracia iliberal \\
\hline
\end{tabular}

\begin{tabular}{|l|l|}
\hline \multicolumn{2}{|l|}{ Paraguai } \\
\hline $1978-1988$ & não-democracia linha dura \\
\hline 1989 & não-democracia moderada \\
\hline $1990 \cdot 1992$ & semidemocracia iliberal \\
\hline $1993 \cdot 2004$ & democracia iliberal \\
\hline
\end{tabular}

\begin{tabular}{|l|l|}
\hline \multicolumn{2}{|c|}{ Uruguai } \\
\hline $1978 \cdot 1980$ & não-democracia linha dura \\
\hline $1981 \cdot 1984$ & não-democracia moderada \\
\hline $1985 \cdot 2004$ & democracia liberal \\
\hline
\end{tabular}

\begin{tabular}{|l|l|}
\hline \multicolumn{2}{|l|}{ Panamá } \\
\hline $1978-1979$ & não-democracia linha dura \\
\hline $1980 \cdot 1983$ & não-democracia moderada \\
\hline $1984-1985$ & semidemocracia iliberal \\
\hline 1986 & não-democracia moderada \\
\hline $1987 \cdot 1989$ & não-democracia linha dura \\
\hline $1990 \cdot 1991$ & semidemocracia liberal \\
\hline $1992 \cdot 1993$ & semidemocracia iliberal \\
\hline $1994-1999$ & democracia iliberal \\
\hline $2000-2004$ & democracia liberal \\
\hline
\end{tabular}

\section{Peru}

\begin{tabular}{|l|l|}
\hline \multicolumn{2}{|c|}{ Peru } \\
\hline $1978-1979$ & não-democracia moderada \\
\hline $1980 \cdot 1991$ & democracia iliberal \\
\hline 1992 & não-democracia linha dura \\
\hline 1993 & semidemocracia repressiva \\
\hline $1994-2000$ & semidemocracia iliberal \\
\hline $2001 \cdot 2004$ & democracia iliberal \\
\hline
\end{tabular}

\begin{tabular}{|l|l|}
\hline \multicolumn{2}{|c|}{ República Dominicana } \\
\hline 1978 & democracia liberal \\
\hline $1979 \cdot 1980$ & democracia iliberal \\
\hline $1981 \cdot 1983$ & democracia liberal \\
\hline $1984-1999$ & democracia iliberal \\
\hline $2000 \cdot 2004$ & democracia liberal \\
\hline
\end{tabular}

\begin{tabular}{|l|l|}
\hline \multicolumn{2}{|l|}{ Venezuela } \\
\hline $1978-1988$ & democracia liberal \\
\hline $1989 \cdot 1998$ & democracia iliberal \\
\hline 1999 & semidemocracia iliberal \\
\hline $2001 \cdot 2001$ & semidemocracia repressiva \\
\hline $2002 \cdot 2004$ & semidemocracia iliberal \\
\hline
\end{tabular}




\section{Anexo 3}

\section{Dados e fontes}

\begin{tabular}{|c|c|c|}
\hline $\begin{array}{l}\text { Descrição da variável (todos } \\
\text { os países-anos, 1978-2004) }\end{array}$ & Codificação & Fonte \\
\hline \multicolumn{3}{|l|}{ Variáveis dependentes } \\
\hline $\begin{array}{l}\text { Transições rumo à } \\
\text { democracia liberal (Totdem) }\end{array}$ & $\begin{array}{l}0 \text { = nenhuma transição no ano considerado } \\
1 \text { = qualquer transição na direção da } \\
\text { democracia liberal no ano considerado (p.ex., } \\
\text { uma transição da semidemocracia à } \\
\text { democracia iliberal é codificada como 1) }\end{array}$ & $\begin{array}{l}\text { Smith \& Ziegler } \\
2006\end{array}$ \\
\hline $\begin{array}{l}\text { Transições de iliberal a } \\
\text { liberal (Ilibalib) }\end{array}$ & $\begin{array}{l}0=\text { nenhuma transição ilibalib } \\
1=\text { qualquer transição ilibalib }\end{array}$ & Ibid. \\
\hline \multicolumn{3}{|l|}{$\begin{array}{l}\text { Variáveis independents: } \\
\text { políticas }\end{array}$} \\
\hline $\begin{array}{l}\text { Experiências prévias com a } \\
\text { democracia (Prévias) }\end{array}$ & $\begin{array}{l}\text { Número de experiências democráticas (p.ex., } \\
0=\text { nunca foi democrático; } 4=4 \text { transições } \\
\text { rumo à democracia eleitoral) }\end{array}$ & $\begin{array}{l}\text { Smith 2005: } \\
\text { Anexo } 1\end{array}$ \\
\hline Duração do regime (DurReg) & $\begin{array}{l}\text { Duração do regime em anos, codificada para } \\
\text { cada ano }\end{array}$ & $\begin{array}{l}\text { Smith \& Ziegler } \\
2006\end{array}$ \\
\hline $\begin{array}{l}\text { Duração da democracia } \\
\text { (DurDem) }\end{array}$ & $\begin{array}{l}\text { Duração do regime democrático em anos, } \\
\text { codificada para cada ano (p.ex., Costa Rica = } \\
1 \text { em 1953, } 21 \text { em 1973). }\end{array}$ & $\begin{array}{l}\text { Ibid. } \\
\text { Smith } 2005\end{array}$ \\
\hline $\begin{array}{l}\text { Ano de eleição presidencial } \\
\text { (Eleição) }\end{array}$ & $\begin{array}{l}0=\text { Sem eleição presidencial no ano } \\
\text { considerado } \\
1=\text { Com eleição presidencial no ano } \\
\text { considerado } \\
\text { Casos excluídos quando a transição Totdem } \\
\text { ou llibalib precederam a eleição }\end{array}$ & Ibid. \\
\hline $\begin{array}{l}\text { Experiência prévia com a } \\
\text { democracia (Prévia) }\end{array}$ & $\begin{array}{l}0=\text { Nenhuma experiência prévia com a } \\
\text { democracia } \\
1=\text { Qualquer experiência prévia com a } \\
\text { democracia }\end{array}$ & Ibid. \\
\hline Subregião & $\begin{array}{l}0=\text { América do Sul } \\
1=\text { América Central e Caribe }\end{array}$ & $\begin{array}{l}\text { Banco Mundial } \\
2004\end{array}$ \\
\hline \multicolumn{3}{|l|}{$\begin{array}{l}\text { Variáveis independents: } \\
\text { socioeconômicas }\end{array}$} \\
\hline $\begin{array}{l}\text { Manifestações contra o } \\
\text { governo (Manifestações) }\end{array}$ & Número de manifestações contra o governo & Banks 2006 \\
\hline Distúrbios & Número de distúrbios & Ibid. \\
\hline Greves gerais (Greves) & Número de greves gerais & Ibid. \\
\hline $\begin{array}{l}\text { Crescimento do PIB } \\
\text { (PIBcresc) }\end{array}$ & $\%$ a.a. & $\begin{array}{l}\text { Banco Mundial } \\
2004\end{array}$ \\
\hline $\begin{array}{l}\text { Deflator da defasagem } \\
\text { inflacionária (Inflação) }\end{array}$ & $\%$ a.a., defasagem de 1 ano & Ibid. \\
\hline PIB do ano corrente (PIB) & PIB em US\$ & Ibid. \\
\hline $\begin{array}{l}\text { Agricultura, valor adicionado } \\
\text { (Agricultura) }\end{array}$ & $\%$ do PIB & Ibid. \\
\hline $\begin{array}{l}\text { Matriculados em escolas } \\
\text { secundárias (Matriculados) }\end{array}$ & $\begin{array}{l}\text { Número de matriculados como \% do grupo } \\
\text { etário }\end{array}$ & Ibid. \\
\hline
\end{tabular}


Peter H. Smith - phsmith@weber.ucsd.edu

Melissa R. Ziegler - mrziegle@ucsd.edu

Tradução do original em inglês de Sebastião Nascimento

(Uma versão deste artigo foi publicada em Latin American Politics and Society, v.50, n 1, 2008. Estas tradução e publicação têm a permissão da University of Miami and Wiley-Blackwell).

Recebido para publicação em abril de 2008.

Aprovado para publicação em abril de 2008. 